\title{
Hubungan Infeksi Soil Transmitted Helminth dengan Status Gizi pada Murid SDN 29 Purus Padang
}

\author{
Reshka Renanti $\mathrm{M}^{1}$, Selfi Renita Rusjdi ${ }^{2}$, Elmatris $S Y^{3}$
}

\begin{abstract}
Abstrak
Anak usia sekolah merupakan golongan yang sering teinfeksi cacing Soil Transmitted Helminth (STH) karena sering berkontak dengan tanah. Infeksi STH dapat menimbulkan kerugian zat gizi, kehilangan darah, serta menurunkan ketahanan tubuh sehingga mudah terkena penyakit. Tujuan penelitian ini adalah untuk mengetahui hubungan antara infeksi soil transmitted helminth dengan status gizi. Penelitian dengan pendekatan cross sectional ini dilakukan di Sekolah Dasar Negeri 29 Purus Padang yang dilaksanakan dari Oktober 2014 sampai dengan Februari 2015. Populasi adalah semua murid SDN 29 Purus dengan jumlah subjek 78 orang. Pengambilan subjek dengan multistage sampling. Instrumen penelitian yaitu pemeriksaan feses dengan metode Kato-Katz dan pengukuran berat badan serta tinggi badan. Metode analisa data adalah Chi square dengan derajat kepercayaan $90 \%$. Hasil penelitian menunjukkan lebih dari separuh (51,3\%) murid SDN 29 Purus Padang tahun 2014 menderita infeksi STH dan infeksi campuran A. lumbricoides dan T. trichiura sebanyak 23,1\%. Status gizi berdasarkan BB/U sebagian besar (82,1\%) memiliki gizi baik, berdasarkan TB/U sebagian besar (71,8\%) memiliki tinggi normal dan berdasarkan BB/TB sebagian besar (91\%) adalah normal. Murid SDN 29 Purus Padang yang positif terinfeksi STH sebagian besar (87,5\%) memiliki gizi baik, sebagian besar (72,5\%) memiliki tinggi normal dan sebagian besar (92,5\%) memiliki gizi normal. Kesimpulan penelitian ini ialah tidak terdapat hubungan secara statistik antara infeksi STH dengan status gizi $(p>0,05)$.
\end{abstract}

Kata kunci: soil transmitted helminth, status gizi, infeksi

\begin{abstract}
School-age children are often exposed to a class of worm Soil Transmitted Helminth (STH) because of frequent contact with the ground. STH infections can lead to loss of nutrients, blood loss and decreased health, so susceptible to disease. The objective of this study was to determine the relationship between soil transmitted helminth infections and nutritional status. This cross sectional study was conducted at the SDN 29 Purus Padang from October 2014 until February 2015. The subjects were 78 students of SDN 29 Purus. Sampling by multistage sampling. The research instrument used was a stool examination with Kato-Katz method and measurements of weight and height. The method of data analysis is Chi-square with degrees of confidence of $90 \%$. The results showed more than half (51.3\%) students of SDN 29 Purus Padang 2014 got STH infections and mixed infection of A. lumbricoides and T. trichiura as much as 23.1\%. Nutritional status based on W / A majority (82.1\%) had good nutrition, based TB / U majority (71.8\%) had a normal high and based on W/ H majority (91\%) were normal. Students of SDN 29 Purus positive Padang infected STH majority (87.5\%) had good nutrition, the majority (72.5\%) had a normal height and the majority (92.5\%) had a normal nutrition. It can be concluded that there is no statistically significant relationship soil transmitted helminth infections and nutritional status ( $p>0.05$ ).
\end{abstract}

Keywords: soil transmitted helminth, nutritional status, infections

Affiliasi penulis : 1. Pendidikan Dokter FK UNAND (Fakultas Kedokteran Universitas Andalas Padang), 2. Bagian Parasitologi FK UNAND , 3. Bagian Kimia FK UNAND.
Korespondensi: Reshka Renanti M, E-mail:

reshkarenanti@yahoo.co.id, Telp: 081374906710 


\section{PENDAHULUAN}

Soil Transmitted Helminth (STH) adalah cacing yang penularannya lewat tanah dan jenis cacing yang sering ditemukan yaitu Ascaris lumbricoides, Trichuris trichiura, Ancylostama duodenale dan Necator americanus. ${ }^{1}$ Laporan WHO tahun 2006 mengatakan bahwa infeksi Ascaris lumbricoides mencapai 1 milyar orang, Trichuris trichiura 795 juta orang dan cacing tambang (Ancylostama duodenale dan Necator americanus) 740 juta orang. Di Asia tenggara, infeksi cacing STH mencapai 500 juta orang dan 11 negara dikategorikan sebagai endemis dan Indonesia merupakan salah satu dari 11 negara tersebut. ${ }^{2}$

Prevalensi STH di Indonesia pada umumnya masih sangat tinggi yaitu sebesar $60 \%$, terutama pada golongan penduduk yang kurang mampu mempunyai risiko tinggi terjangkit penyakit ini. ${ }^{3}$ Hasil survei kecacingan 2009 di Indonesia oleh Ditjen P2PL menyebutkan 31,8\% siswa Sekolah Dasar (SD) menderita kecacingan. ${ }^{4}$

Dalam laporan hasil survey prevalensi infeksi cacing pada 10 propinsi tahun 2004, Sumatera Utara menduduki peringkat ke-3 $(60,4 \%)$ dalam hal penyakit cacingan setelah Sumatera Barat $(82,3 \%)$ dan Nusa Tenggara Barat $(83,6 \%)$. Angka nasional adalah $30,35 \%$ dengan rincian prevalensi cacing gelang $17,75 \%$, cacing cambuk $17,74 \%$ dan cacing tambang $6,46 \%$. Berdasarkan hasil pemeriksaan tinja yang dilakukan pada 8 provinsi di Indonesia tahun 2008, didapat angka prevalensi kecacingan yang tinggi, yakni Banten 60,7\%, Nanggroe Aceh Darussalam $59,2 \%$, Nusa Tenggara Timur 27,7\%, Kalimantan barat $26,2 \%$, Sumatera Barat $10,1 \%$, Jawa Barat 6,7\%, Sulawesi Utara 6,7\% dan Kalimantan Tengah $5,6 \%{ }^{5}$

Beberapa penelitian tentang infeksi cacing ternyata menunjukkan bahwa anak usia sekolah merupakan golongan yang sering terkena infeksi cacing karena sering berhubungan dengan tanah. ${ }^{5}$ Infeksi cacing dapat menimbulkan kerugian zat gizi berupa kalori dan protein serta kehilangan darah. Selain dapat menghambat perkembangan fisik, kecerdasan dan produktifitas kerja, dapat juga menurunkan ketahanan tubuh sehingga mudah terkena penyakit lainnya. ${ }^{3}$
Prevalensi status gizi nasional anak usia sekolah laki-laki yang kurus adalah $13,3 \%$, sedangkan perempuan adalah $10,9 \% .{ }^{6}$ Berdasarkan data Dinkes Kota Padang tahun 2013 didapatkan hasil skrining murid SD terdapat 7,6\% anak yang kurus dan 1,6\% anak yang kurus sekali. ${ }^{7}$ Hasil skrining murid SD kelas-1 di Puskesmas Padang Pasir tahun 2014 terdapat 74 anak yang kurus sekali dan 3 anak yang kurus. ${ }^{8}$ Anak yang tidak terinfeksi cacing memiliki status gizi yang relatif lebih baik dibandingkan anak yang terinfeksi cacing. ${ }^{9}$

Purus termasuk Kelurahan di Kecamatan Padang Barat yang terletak dipinggir pantai, dimana penduduknya padat dan kumuh serta kebanyakan masyarakat masih belum mempunyai jamban sendiri. Di Purus terdapat beberapa sekolah yang salah satunya adalah SDN 29 Purus terletak disebelah sungai kecil yang biasa digunakan sebagai jamban oleh masyarakat. Hasil observasi didapatkan informasi tentang kebiasaan anak-anak yang suka bermain dengan tanah, rata-rata tinggal di sekitar pantai, belum adanya kebiasaan mencuci tangan setelah bermain serta status ekonomi yang masih rendah. Ini termasuk faktor-faktor yang menunjang untuk terjadinya infeksi STH di SDN 29 Purus Padang. Berdasarkan hasil pra penelitian yang dilakukan peneliti didapatkan $25 \%$ dari 60 sampel menderita askariasis dan ada 10\% anak yang menderita infeksi campuran.

Berdasarkan uraian diatas dan masih tingginya prevalensi askariasis maka dilakukan penelitian tentang hubungan infeksi Soil Transmitted Helminths dengan status gizi murid SDN 29 Purus Padang.

\section{METODE}

Penelitian yang dilakukan di Sekolah Dasar Negeri 29 Purus Padang merupakan penelitian analitik dengan pendekatan cross sectional yang dilaksanakan dari Oktober 2014 sampai Februari 2015. Populasi adalah semua murid SDN 29 Purus dengan jumlah subjek 78 orang. Pengambilan subjek dengan teknik multistage sampling. Instrumen penelitian yang digunakan yaitu pemeriksaan feses dengan metode Kato-Katz yang dilakukan di laboratorium Parasitologi Fakultas Kedokteran Universitas Andalas. Metode analisis data adalah Chi square dengan derajat 
kepercayaan $90 \%$.

HASIL

Tabel 1. Distribusi frekuensi infeksi STH pada murid SDN 29 Purus Padang

\begin{tabular}{lcc}
\hline Karakteristik & $\mathbf{f}$ & $\%$ \\
\hline Infeksi & 38 & $48,7 \%$ \\
Negatif & 40 & $51,3 \%$ \\
Positif & & \\
Spesies Cacing & 16 & $20,5 \%$ \\
Ascaris lumbricoides & 10 & \\
$\quad$ Ringan & 5 & \\
Sedang & 1 & \\
Berat & 6 & $7,7 \%$ \\
Trichuris trichiura & 5 & \\
Ringan & 1 & \\
Sedang & 18 & $23,1 \%$ \\
Ascaris lumbricoides+ & & \\
Trichuris trichiura & 7 & \\
Ringan+Ringan & 2 & \\
Ringan+Sedang & 6 & \\
Sedang+Ringan & 1 & \\
Sedang+Sedang & 1 & \\
Berat+Ringan & &
\end{tabular}

Tabel 1 memperlihatkan status infeksi lebih dari separuh (51,3\%) murid menderita infeksi STH. Berdasarkan spesies cacing yang banyak ditemukan yaitu infeksi campuran Ascaris lumbricoides dan Trichuris trichiura sebanyak 18 orang $(23,1 \%)$.

Tabel 2. Distribusi frekuensi status gizi pada murid SDN 29 Purus Padang

\begin{tabular}{lcc}
\hline Status Gizi & $\mathbf{f}$ & $\%$ \\
\hline BB/U (Berat Badan/Umur) & 14 & $17,9 \%$ \\
$\quad$ Kurang & 64 & $82,1 \%$ \\
$\quad$ Baik & & \\
TB/U (Tinggi Badan/Umur) & 3 & $3,8 \%$ \\
$\quad$ Sangat Pendek & 19 & $24,4 \%$ \\
Pendek & 56 & $71,8 \%$ \\
Normal & & \\
BB/TB (Berat Badan/Tinggi Badan) & 2 & $2,6 \%$ \\
Sangat Kurus & 3 & $3,8 \%$ \\
Kurus & 71 & $91 \%$ \\
Normal & 2 & $2,6 \%$ \\
$\quad$ Gemuk & & \\
\hline
\end{tabular}

Tabel 2 memperlihatkan status gizi berdasarkan BB/U sebagian besar murid (82,1\%) memiliki gizi baik, berdasarkan TB/U sebagian besar murid (71,8\%) memiliki tinggi normal dan pada umumnya $(91,0 \%)$ berdasarkan BB/TB adalah normal.

Tabel 3. Hubungan infeksi STH dengan status gizi berdasarkan BB/U pada murid SDN 29 Purus Padang

\begin{tabular}{ccccc}
\hline \multirow{2}{*}{$\begin{array}{c}\text { Infeksi } \\
\text { STH }\end{array}$} & \multicolumn{3}{c}{ Status Gizi } & \multirow{2}{*}{$\mathbf{p}$} \\
\cline { 2 - 4 } & Kurang & Baik & Jumlah & \\
\cline { 2 - 4 } Negatif & $\mathbf{f ( \% )}$ & $\mathbf{f}(\%)$ & $\mathbf{f}(\%)$ & \\
\cline { 2 - 4 } & $9(23,7)$ & $29(76,3)$ & $38(100)$ & 0,321 \\
Positif & $5(12,5)$ & $35(87,5)$ & $40(100)$ & \\
\hline Jumlah & $14(17,9)$ & $64(82,1)$ & $78(100)$ & \\
\hline
\end{tabular}

Tabel 3 memperlihatkan murid SDN 29 Purus Padang yang positif terinfeksi STH terlihat sebagian besar $(87,5 \%)$ memiliki gizi baik. Hasil uji statistik menunjukkan tidak terdapat hubungan antara infeksi STH dengan status gizi berdasarkan BB/U dengan $p$ value $0,321(p>0,05)$.

Tabel 4. Hubungan infeksi STH dengan status gizi berdasarkan TB/U pada murid SDN 29 Purus Padang

\begin{tabular}{cccccc}
\hline \multirow{2}{*}{$\begin{array}{c}\text { Infeksi } \\
\text { STH }\end{array}$} & $\mathbf{5}$ & $\mathbf{P}$ & $\mathbf{N}$ & $\mathbf{J l h}$ & $\mathbf{p}$ \\
\cline { 2 - 5 } & $\mathbf{f ( \% )}$ & $\mathbf{f}(\%)$ & $\mathbf{f}(\%)$ & $\mathbf{f}(\%)$ & \\
\cline { 2 - 5 } Negatif & $1(2,6)$ & $10(26,3)$ & $27(71,1)$ & $38(100)$ & 0,816 \\
Positif & $2(5)$ & $9(22,5)$ & $29(72,5)$ & $40(100)$ & \\
\hline Jlh & $3(3,8)$ & $19(24,4)$ & $56(71,8)$ & $78(100)$ & \\
\hline Keterangan : SP (Sangat Pendek), P (Pendek), N (Normal), & & \\
& Jlh (Jumlah). &
\end{tabular}

Tabel 4 memperlihatkan murid SDN 29 Purus Padang yang positif terinfeksi STH terlihat sebagian besar $(72,5 \%)$ memiliki tinggi yang normal. Hasil uji statistik menunjukkan tidak terdapat hubungan antara infeksi STH dengan status gizi berdasarkan TB/U dengan $p$ value $0,816(p>0,05)$. 
Tabel 5. Hubungan infeksi STH dengan status gizi berdasarkan BB/TB pada murid SDN 29 Purus Padang

\begin{tabular}{ccccccc}
\hline Infeksi & \multicolumn{4}{c}{ Status Gizi } & \multicolumn{1}{c}{$\mathbf{p}$} \\
\cline { 2 - 6 } STH & $\mathbf{S K}$ & $\mathbf{K}$ & $\mathbf{N}$ & $\mathbf{G}$ & $\mathbf{J l h}$ & \\
\cline { 2 - 6 } Negatif & $\mathbf{f}(\%)$ & $\mathbf{f ( \% )}$ & $\mathbf{f ( \% )}$ & $\mathbf{f ( \% )}$ & $\mathbf{f ( \% )}$ & \\
\cline { 2 - 6 } & 1 & 2 & 34 & 1 & 38 & 0,938 \\
Positif & 1 & 1 & 37 & 1 & 40 & \\
& $(2,5)$ & $(2,5)$ & $(92,5)$ & $(2,5)$ & $(100)$ & \\
\hline Jlh & 2 & 3 & 71 & 2 & 78 & \\
& $(2,6)$ & $(3,8)$ & $(91)$ & $(2,6)$ & $(100)$ &
\end{tabular}

Keterangan : SK (Sangat Kurus), K (Kurus), N (Normal), G (Gemuk), Jlh (Jumlah).

Tabel 5 memperlihatkan murid SDN 29 Purus Padang yang positif terinfeksi STH terlihat sebagian besar $(92,5 \%)$ memiliki gizi normal. Hasil uji statistik tidak terdapat hubungan antara infeksi STH dengan status gizi berdasarkan BB/TB dengan $p$ value 0,938 $(p>0,05)$.

\section{PEMBAHASAN}

\section{Hubungan infeksi STH dengan status gizi berdasarkan BB/U}

Hasil uji statistik Chi-square tentang hubungan infeksi Soil Transmitted Helminths dengan status gizi berdasarkan BB/U didapatkan $p$ value 0,05 sehingga tidak terdapat hubungan infeksi Soil Transmitted Helminths dengan status gizi berdasarkan BB/U.

Pada tabel 3, murid yang gizi kurang banyak terdapat pada murid yang tidak terinfeksi Soil Transmitted Helminths sedangkan murid dengan gizi baik banyak terdapat pada murid yang terinfeksi Soil Transmitted Helminths. Hal ini sejalan dengan penelitian Hehy pada tahun 2013 di Manado menunjukkan tidak ada hubungan antara infeksi STH dengan status gizi berdasarkan $\mathrm{BB} / \mathrm{U} .^{10}$

Dari hasil penelitian ini dapat dilihat tidak selalu seorang anak yang mempunyai status gizi kurang dipengaruhi oleh adanya kecacingan, tetapi ada faktor-faktor lain yang mempengaruhi status gizi. Masalah gizi kurang bisa disebabkan oleh kemiskinan, kurangnya persediaan pangan, kurang baiknya kualitas lingkungan (sanitasi), kurangnya pengetahuan masyarakat tentang gizi. ${ }^{11}$

\section{Hubungan infeksi STH dengan status gizi berdasarkan TB/U}

Hasil uji statistik Chi-square tentang hubungan infeksi Soil Transmitted Helminths dengan status gizi berdasarkan $\mathrm{BB} / \mathrm{U}$ didapatkan $p$ value $>0,05$ sehingga tidak terdapat hubungan infeksi SoilTransmitted Helminths dengan status gizi berdasarkan TB/U.

Pada tabel 4 didapatkan murid yang sangat pendek lebih banyak pada murid yang menderita infeksi STH sedangkan pada murid yang pendek lebih banyak ditemukan pada murid yang tidak menderita infeksi STH. Penelitian yang dilakukan oleh Hehy pada tahun 2013 di Manado menunjukkan tidak ada hubungan antara infeksi STH dengan status gizi berdasarkan TB/U. Penelitian oleh Wijianingsih pada tahun 2011juga menunjukkan tidak terdapat hubungan antara infeksi STH dengan status gizi. ${ }^{12}$

Status gizi berdasarkan TB/U menggambarkan masalah gizi kronis. Pada murid SDN 29 Purus Padang masih didapatkan murid yang pendek dan sangat pendek yang bisa disebabkan saat balita asupan gizi kurang sehingga berpengaruh terhadap proses pertumbuhannya. Selain itu, kurang gizi saat ibu hamil juga membuat perkembangan bayi kurang optimal, pertumbuhan terganggu sehingga anak menjadi pendek.

\section{Hubungan infeksi STH dengan status gizi berdasarkan $\mathrm{BB} / \mathrm{TB}$}

Hasil uji statistik Chi-square tentang hubungan infeksi Soil Transmitted Helminths dengan status gizi berdasarkan $\mathrm{BB} / \mathrm{U}$ didapatkan $p$ value> 0,05 sehingga tidak terdapat hubungan infeksi Soil Transmitted Helminths dengan status gizi berdasarkan BB/TB.

Pada Tabel 5 didapatkan murid yang sangat kurus sama banyaknya antara murid yang tidak menderita infeksi STH dengan murid yang menderita STH. Murid yang kurus lebih banyak pada murid yang tidak menderita infeksi STH. Penelitian yang dilakukan oleh Hehy pada tahun 2013 di Manado menunjukkan tidak ada hubungan antara infeksi STH dengan status gizi berdasarkan BB/TB. ${ }^{10}$ Penelitian oleh Fatimah pada tahun 2012 juga menunjukkan tidak ada hubungan antara infeksi STH dengan status gizi berdasarkan $\mathrm{BB} / \mathrm{TB} .{ }^{13}$ 
Pada murid SDN 29 Purus Padang masih ditemukan murid yang sangat kurus dan kurus yang berarti masih terdapat masalah gizi. Hasil analisa didapatkan tidak ada hubungan infeksi STH dengan status gizi berdasarkan BB/U, TB/U, BB/TB. Ini menandakan bahwa status gizi pada murid SDN 29 Purus Padang bisa dipengaruhi hal lain selain kecacingan.

Pada dasarnya seiring dengan pertambahan usia anak maka makanan yang diberikan harus bergizi dan seimbang dimana hal ini penting untuk menunjang tumbuh kembang anak termasuk kecerdasannya. Dalam hal pengaturan pola makan, orang tua mempunyai peran yang sangat penting dalam memilih jenis makanan. Dikatakan juga bahwa bila terdapat kebiasaan makan yang jelek pada anak, selain dipengaruhi oleh kebiasaan keluarga yang jelek juga dipengaruhi oleh pendapatan keluarga yang rendah. ${ }^{14}$

Faktor ekonomi keluarga yang rendah bisa menyebabkan kurang asupan makanan yang dibutuhkan anak untuk pertumbuhan dan perkembangan sehingga menyebabkan gizi kurang dan bisa berakibat anak mudah terserang penyakit lain. Berdasarkan penelitian Harniwita pada tahun 2008 di Desa Buluh Cina Kecamatan Siak Hulu Kabupaten Kampar menunjukkan ada hubungan antara tingkat pendapatan dengan status gizi keluarga karena pada kondisi ekonomi yang terbatas maka pemenuhan gizi pada anak juga terbatas. ${ }^{15}$ Tingkat pendidikan orang tua terutama ibu juga berpengaruh terhadap gizi anak karena semakin tinggi pendidikan ibu maka diharapkan semakin tinggi pengetahuan ibu tentang kesehatan termasuk gizi sehingga anak mendapatkan makanan bergizi. Berdasarkan penelitian Sutanto, Mututik dan Suwarni pada tahun 2012, menunjukkan ada hubungan antara tingkat pengetahuan ibu dengan status gizi di Desa Tanjung Kecamatan Nguter Kabupaten Sukoharjo. Pengetahuan dan sikap ibu tentang gizi dapat mempengaruhi pemberian makanan, kesehatan dan pemantauan pertumbuhan serta perkembangan anakanaknya. $^{16}$

\section{KESIMPULAN}

Lebih dari separuh murid SDN 29 Purus Padang tahun 2014 menderita infeksi Soil Transmitted Helminth.

Intensitas infeksi Soil Transmitted Helminths adalah intensitas ringan dan banyak ditemukan infeksi campuran Ascaris lumbricoides dan Trichuris trichiura.

Status gizi pada murid SDN 29 Purus Padang rata-rata memiliki gizi baik (normal).

Tidak terdapat hubungan infeksi STH dengan status gizi berdasarkan BB/U, TB/U, BB/TB

\section{UCAPAN TERIMA KASIH}

Ucapan terima kasih kepada dr. Selfi Renita Rusjdi, M.Biomed dan Dra. Elmatris SY,MSatas bimbingan, bantuan dan motivasi dalam penelitian ini.

\section{DAFTAR PUSTAKA}

1. Gandahusada S. Parasitologi kedokteran. Jakarta: Fakultas Kedokteran Universitas Indonesia;2006.

2. World Health Organization. Intestinal worms, soil transmitted helminths. Ganeva: World Health Organization; 2006.

3. Departemen Kesehatan RI. Lampiran KMK: pedoman pengendalian cacingan. Jakarta; 2006.

4. Departemen Kesehatan RI. Profil kesehatan Indonesia 2009. Jakarta; 2010.

5. Departemen Kesehatan RI. PPM-PL Tahun 2004. Ditjend PPM-PL: Jakarta; 2004.

6. Riset Kesehatan Dasar. Laporan nasional 2007. Jakarta: Badan Penelitian dan Pengembangan Kesehatan Departemen Kesehatan RI; 2007.

7. Dinas Kesehatan Kota Padang. Rekap hasil skrening kesehatan murid SD Puskesmas Kota Padang; 2013.

8. Puskesmas Padang Pasir. Rekap skrening kesehatan murid SD kecamatan Padang Barat; 2014.

9. Elmi ST, Dewiyani BS, Hamid ED, Pasaribu S, Lubis CP. Status gizi dan infestasi cacing usus pada anak sekolah dasar (skripsi). Medan: 
Universitas Sumatera Utara; 2004.

10. Hehy G A, Basuki A. Hubungan antara kecacingan dengan status gizi pada anak sekolah dasar di Kelurahan Bunaken Kecamatan Bunaken Kota Manado[serial online 2013 (diunduh 29 Desember 2014). Tersedia dari: URL: HYPERLINK www.fkm.unsrat.ac.id

11. Almatsier S. Prinsip dasar ilmu gizi. Jakarta: Gramedia Pustaka Utama; 2001.

12. Wijianingsih SY. Hubungan antara infeksi kecacingan dengan anemia dan status gizi pada siswa SDN Purwosari kecamatan Tamban Kabupaten Barito Kuala [serial online] 2011 (diunduh 29 Desember 2014).Tersedia dari: URL: HYPERLINKwww.perpustakaanhb.files.wordpress. com.

13. Fatimah F. Derajat keparahan infeksi STH terhadap status gizi dan anemia pada anak sekolah dasar [serial online] 2012 (diunduh 30 Desember 2014). Tersedia dari: URL: HYPERLINK www.i-lib.ugm.ac.id.

14. Gibeon. Gambaran kecenderungan status gizi anak baru masuk sekolah dasar di Kematan Medan Sunggal Tahun 2007-2010 (skripsi). Medan: Universitas Sumatera Utara; 2010.

15. Harniwita. Pengaruh tingkat pendapatan terhadap gizi keluarga di desa Buluh Cina kecamatan Siak Hulu Kabupaten Kampar [serial online] 2008 (diunduh 6 Januari 2015). Tersedia dari: URL: HYPERLINK www.journal.uad.ac.id.

16. Sutanto A, Mututik L, Suwarni A. Hubungan antara tingkat pengetahuan ibu dengan status gizi anak di desa Tanjung kecamatan Nguter kabupaten Sukoharjo [serial online] 2012 (diunduh 4 Januari 2015). Tersedia dari: URL: HYPERLINK www.fkm.unsrat.ac.id. 